\title{
Immunogenetics and clinical phenotype of sympathetic ophthalmia in British and Irish patients
}

Dara J Kilmartin, David Wilson, Janet Liversidge, Andrew D Dick, Julia Bruce, Robert W Acheson, Stanislaw J Urbaniak, John V Forrester

\begin{abstract}
Backgroundlaims-Sympathetic ophthalmia (SO) is a classic example of autoimmune disease where human leucocyte antigen (HLA) genomic associations could provide further understanding of mechanisms of disease. This study sought to assess HLA genetic polymorphism in British and Irish patients with SO, and to assess whether HLA gene variants are associated with clinical phenotype or disease severity.

Methods-High resolution DNA based HLA typing using polymerase chain reaction sequence specific primers was performed in 27 patients with SO and 51 matched healthy controls. Clinical phenotype and markers of disease severity were determined prospectively in 17 newly diagnosed patients and from medical record review and repeat clinical examination in 10 previously diagnosed patients.
\end{abstract}

Results-HLA-Cw*03 (p=0.008), DRB1*04 $(p=0.017)$, and DQA1 ${ }^{\star} 03(p=0.014)$ were significantly associated with SO. For class II alleles at higher resolution, only HLA-DRB1 ${ }^{\star} 0404$ (relative risk $(R R)=5.6$, $\mathbf{p}=0.045)$ was significantly associated with SO. The highest relative risk for any of the associated haplotypes was with HLA-DRB $1{ }^{\star} 0404-D Q A 1{ }^{\star} 0301 \quad(R R=10.9$, $p=0.019)$. Patients with the DRB1*04DQA1*03 associated haplotype were significantly more likely to develop SO earlier, with fewer inciting ocular trauma events, and to require more systemic steroid therapy to control inflammatory activity.

Conclusions-Sympathetic ophthalmia is associated with HLA-DRB1*04 and DQA ${ }^{\star} 03$ genotypes in white patients, similar to Japanese patients. Differences in $D R B 1 \star 04$ gene variant associations (-0404 in Britain and Ireland and -0405 in Japan) may have implications for HLA peptide binding in disease initiation. The DRB1*04-DQA1*03 haplotype is a marker of increased SO susceptibility and severity, as in Vogt-Koyanagi-Harada disease, which also has similar clinicopathological and HLA associations.

(Br f Ophthalmol 2001;85:281-286)

Sympathetic ophthalmia (SO) is an uncommon cause of bilateral granulomatous posterior uveitis which follows injury to one eye, from ocular surgery or penetrating ocular trauma. Although rare, with a recent reported incidence of $0.03 / 100000,{ }^{1}$ it remains a serious eye disease because of its potentially blinding effects on both the exciting injured eye and the contralateral sympathising eye and usually the patient is committed to receiving chronic immunosuppressive therapy to preserve good vision. ${ }^{12} \mathrm{SO}$ is one of the most feared complications of ocular surgery, and recent evidence shows that the proportion of $\mathrm{SO}$ cases following retinal surgery is increasing. ${ }^{12} \mathrm{SO}$ is also of particular interest to immunologists as it is regarded as the prototype for autoimmune disease, where breaching of systemic ocular barriers compromises the relative immune privilege of the eye, and causes sensitisation to previously sequestered uveoretinal antigens. Although many candidate ocular antigens have been implicated, ${ }^{3-5}$ the precise autoantigen, or disease inducing peptide, has yet to be determined.

Endogenous posterior uveitis (EPU) is a CD4+ $\mathrm{T}$ (helper) cell mediated disease $\mathrm{e}^{3}$ and, in $\mathrm{SO}$, both peripheral blood and vitreous $\mathrm{T}$ lymphocytes have been shown to be reactive to retinal antigen stimulation. ${ }^{5}$ Immunohistochemistry of enucleated exciting eyes in $\mathrm{SO}$ has demonstrated the pathogenic role of both CD4+ $\mathrm{T}$ cells in the initial stages of disease, and CD8+ T (suppressor) cells in later stages. ${ }^{6}$ Human leucocyte antigen (HLA) associations with autoimmune disease are central to understanding disease mechanisms in ocular inflammatory disease, including SO. HLA gene products, through peptide-HLA binding affinity, can uniquely influence the presentation of disease inducing peptides, or adjust the development of the $\mathrm{T}$ cell repertoire in the thymus by deleting autoreactive lymphocytes leading to self tolerance. ${ }^{78}$ Certain types of clinical and experimental uveoretinal inflammatory diseases are HLA or major histocompatibility complex (MHC) restricted-for example, birdshot retinochoroidopathy, Behçet's disease, Vogt-Koyanagi-Harada's disease (VKH), and experimental autoimmune uveoretinitis, and individuals possessing the HLA/MHC susceptibility gene have increased disease severity in both human and animal disease. ${ }^{9-13}$ A precise HLA association with SO could provide further understanding of mechanisms of disease pathogenesis, help reveal a disease inducing or tolerogenic peptide, and explain variations in clinical phenotype seen in patients with SO.
Accepted for publication 8 November 2000 
Both SO and Vogt-Koyanagi-Harada (VKH) disease have been shown to have similar clinical and immunohistopathological features, and identical associations with HLA class II genes (HLA-DRB $1^{\star} 0405$ and DQB $\left.1{ }^{\star} 0401\right)$ in Japanese patients. ${ }^{12-16}$ In addition, Japanese VKH patients with the HLA-DRB $1{ }^{\star} 0405$ subtype were shown to have significantly increased disease severity. ${ }^{111}$ However, HLA-disease associations are dependent on allelic frequency which varies dramatically from one ethnic group to another. ${ }^{17} 18$ In western SO patients, no DNA based typing has been performed but two older serology based studies found an increase in frequency of HLA-DR ${ }^{19}{ }^{20}$ and HLA-DQ $3 .^{20}$ In this study, we sought to assess HLA genetic polymorphism and the development of SO, and to assess whether HLA gene variants were associated with clinical phenotype or disease severity.

\section{Methods}

PATIENTS AND CONTROLS

Twenty seven patients ( 14 male and 13 female) with newly diagnosed and established SO were recruited from throughout the UK and Ireland. Seventeen newly diagnosed patients were recruited in 1997 and 1998 through the British Ophthalmological Surveillance Unit of the Royal College of Ophthalmologists, as previously reported. ${ }^{1}$ Ten established cases were recruited from uveitis clinics at Grampian University Hospitals, Aberdeen, and the Mater Hospital, Dublin. All patients were white and were native ethnic English (14 patients), Scottish (eight patients), Irish (four patients), and Northern Irish (one patient). All patients had bilateral posterior or panuveitis with a definite history of ocular trauma (accidental or surgical) followed by contralateral posterior uveitis with features clinically consistent with SO. Nineteen patients were diagnosed with $\mathrm{SO}$ by a uveitis subspecialist and eight had been diagnosed by a retina subspecialist. Although the diagnosis of SO was determined clinically, enucleated exciting eyes from five patients demonstrated histological features consistent with SO. All referring ophthalmologists returned questionnaire data on clinical features, and 12 (two newly diagnosed and 10 previously diagnosed) patients had SO clinical features confirmed on examination by three study investigators (DJK, ADD, JVF). Clinical phenotype and markers of disease severity assessed included visual acuity, time interval between SO onset and last ocular injury, number of preceding inciting injuries, ophthalmoscopy features, such as degree of vitreous cellular infiltrate or haze (assessed by slit lamp biomicroscopy and binocular indirect ophthalmoscopy (BIO)), ${ }^{21}$ macular and disc oedema, Dalen-Fuchs nodules and choroidal neovascularisation, and therapeutic interventions such as enucleation and immunosuppressive therapy. Recurrence of uveitis was defined as an increase in disease activity, with worsening of visual acuity and/or BIO score, requiring an increase in immunosuppressive therapy from previously stable maintenance therapy. Median follow up was 12 months (range 6-354 months). Controls for HLA typing were age, sex, and region matched. Two controls were obtained for each patient and these were normal unrelated volunteers without any history of uveitis or other autoimmune disease attending the same hospital or primary care clinic as the patient. This yielded 51 controls for HLA class I and class II (HLA-DRB1, HLA-DQB1) typing, as only one matching control could be obtained for three patients, and 49 controls for HLA-DQA typing as insufficient DNA was available in two controls. Informed consent was obtained from both patients and controls and the study adhered to the tenets of the Declaration of Helsinki. Local institutional review board approval was obtained.

\section{HLA TYPING}

Ten $\mathrm{ml}$ of peripheral blood was obtained from each patient and control and DNA was extracted using the salt extraction method. ${ }^{22}$ HLA class I (A, B, and C) and II (DRB1, DRQA1, and DRQB1) typing was performed using polymerase chain reaction sequence specific primer sets (PCR-SSP) (AllSet and Classic PCR-SSP, Dynal Ltd, Liverpool) based on the method of Olerup. ${ }^{23}$ Initially low resolution typing was performed for class I and II, and then higher resolution typing was repeated for class II subtypes. HLA-DPB1 typing was not performed as the only previous DNA based HLA study of sympathetic ophthalmia found no HLA-DPB1 association. ${ }^{16}$ Briefly, DNA samples were amplified by PCR with 0.38 units per $\mu \mathrm{l}$ of Taq polymerase (Appligene Oncor Lifescreen Ltd, Watford) and nucleotides (final concentration $0.2 \mathrm{mM}$ of each) (Amersham Pharmacia Biotech Ltd, Bucks). All other reagents for PCR were provided in the PCR-SSP sets and used according to manufacturer recommendations. The reaction mixture was processed in an automated thermocycler (Perkin Elmer 9600, Warrington, UK) and subjected to $94^{\circ} \mathrm{C}$ for 2 minutes followed by 10 cycles at $94^{\circ} \mathrm{C}$ for 10 seconds and $65^{\circ} \mathrm{C}$ for 60 seconds, 20 cycles at $94^{\circ} \mathrm{C}$ and $61^{\circ} \mathrm{C}$ for 50 seconds, and $72^{\circ} \mathrm{C}$ for 30 seconds for denaturation, annealing, and extension to allow DNA amplification. After amplification, $10 \mu \mathrm{l}$ of PCR products were electrophoresed in a $2 \%$ agarose gel containing ethidium bromide with $0.5 \%$ TRIS-borate-EDTA buffer. HLA types were assigned on the basis of PCR-SSP patterns using WHO nomenclature. ${ }^{24}$

\section{STATISTICS}

The $\chi^{2}$ test with the continuity correction or Fisher exact test were used to compare patient and control groups. Significance was attributed when the $p$ value was less than 0.05 . The $p$ value was not corrected by the number of comparisons made to correct for the number of alleles. Relative risk (RR) was calculated using the Woolf formula $(a \times d) /(b \times c)$ where $a, b, c$, and $d$ represented the numbers of patients with the marker, patients without the marker, controls with the marker and controls without the marker, respectively. ${ }^{25}$ When a value was 0 , the Haldane modification was used by adding 0.5 to every number. 


\section{Results}

HLA GENOTYPE FREQUENCIES

For British and Irish patients with $\mathrm{SO}$ and healthy controls, the genotype frequencies of HLA class I and class II alleles in are shown in

Table 1 Frequencies of HLA class I alleles in patients with SO

\begin{tabular}{|c|c|c|c|c|c|c|}
\hline \multirow[b]{2}{*}{ Alleles } & \multicolumn{2}{|c|}{ Controls $(n=51)$} & \multicolumn{2}{|c|}{ Patients $(n=27)$} & \multirow[b]{2}{*}{ Relative risk } & \multirow[b]{2}{*}{$p$ Value } \\
\hline & No & $(\%)$ & No & $\%()$ & & \\
\hline$A^{\star} 01$ & 20 & $(39.2)$ & 8 & (29.6) & & \\
\hline $\mathrm{A}^{\star} 02$ & 18 & $(35.3)$ & 13 & $(48.1)$ & & \\
\hline $\mathrm{A}^{\star} 03$ & 15 & $(29.4)$ & 7 & $(25.9)$ & & \\
\hline$A^{\star} 11$ & 8 & (15.7) & 2 & $(7.4)$ & & \\
\hline$A^{\star} 23$ & 1 & $(2.0)$ & 0 & & & \\
\hline$A^{\star} 24$ & 12 & $(23.5)$ & 4 & (14.8) & & \\
\hline$A^{\star} 25$ & 2 & (3.9) & 1 & (3.7) & & \\
\hline$A^{\star} 29$ & 3 & (5.9) & 5 & (18.5) & & \\
\hline$A^{\star} 30$ & 4 & $(7.8)$ & 2 & $(7.4)$ & & \\
\hline$A^{\star} 31$ & 5 & $(9.8)$ & 1 & (3.7) & & \\
\hline$A^{\star} 332$ & 3 & (5.9) & 1 & (3.7) & & \\
\hline$A \star 34$ & 0 & & 1 & (3.7) & & \\
\hline$A^{\star} 68$ & 1 & $(2.0)$ & 1 & $(3.7)$ & & \\
\hline$A^{\star} 74$ & 0 & & 1 & (3.7) & & \\
\hline $\mathrm{B}^{\star} 07$ & 20 & $(39.2)$ & 9 & (33.3) & & \\
\hline $\mathrm{B}^{\star} 08$ & 15 & $(29.4)$ & 9 & (33.3) & & \\
\hline$B^{\star} 14$ & 6 & (11.8) & 3 & (11.1) & & \\
\hline$B^{\star} 15$ & 3 & (3.9) & 2 & (7.4) & & \\
\hline B18 & 2 & (3.9) & 1 & (3.7) & & \\
\hline $\mathrm{B}^{\star} 18$ & 2 & (3.9) & 1 & (3.7) & & \\
\hline $\mathrm{B}^{\star} 27$ & 7 & (13.7) & 1 & (3.7) & & \\
\hline$B^{\star} 35$ & 5 & $(9.8)$ & 1 & $(3.7)$ & & \\
\hline$B \star 37$ & 1 & $(2.0)$ & 1 & (3.7) & & \\
\hline$B \star 39$ & 3 & $(5.9)$ & 0 & & & \\
\hline$B \star 40$ & 4 & $(7.8)$ & 3 & (11.1) & & \\
\hline $\mathrm{B}^{\star} 44$ & 16 & $(31.4)$ & 8 & $(29.6)$ & & \\
\hline$B \star 47$ & 3 & $(5.9)$ & 0 & & & \\
\hline $\mathrm{B}^{\star} 49$ & 1 & $(2.0)$ & 2 & (7.4) & & \\
\hline $\mathrm{B}^{\star} 51$ & 1 & $(2.0)$ & 3 & (11.1) & & \\
\hline$B \star 55$ & 0 & & 2 & $(7.4)$ & & \\
\hline$B \star 57$ & 2 & $(3.9)$ & 0 & & & \\
\hline $\mathrm{B}^{\star} 58$ & 0 & & 1 & $(3.7)$ & & \\
\hline $\mathrm{Cw}^{\star} 01$ & 4 & $(7.8)$ & 1 & $(3.7)$ & & \\
\hline $\mathrm{Cw}^{\star} 02$ & 5 & $(9.8)$ & 1 & (3.7) & & \\
\hline $\mathrm{Cw}^{\star} 03$ & 6 & (11.8) & 11 & $(40.7)$ & 5.2 & 0.008 \\
\hline $\mathrm{Cw}^{\star} 04$ & 8 & (15.7) & 2 & $(7.4)$ & & \\
\hline $\mathrm{Cw}^{\star} 05$ & 9 & $(17.6)$ & 4 & $(14.8)$ & & \\
\hline $\mathrm{Cw}^{\star} 06$ & 10 & $(19.6)$ & 3 & (11.1) & & \\
\hline $\mathrm{Cw}^{\star} 07$ & 37 & $(72.5)$ & 18 & $(66.7)$ & & \\
\hline $\mathrm{Cw}^{\star} 08$ & 4 & $(7.8)$ & 3 & (11.1) & & \\
\hline $\mathrm{Cw}^{\star} 12$ & 0 & & 1 & $(3.7)$ & & \\
\hline $\mathrm{Cw}^{\star} 14$ & 1 & $(2.0)$ & 1 & (3.7) & & \\
\hline $\mathrm{Cw}^{\star} 15$ & 0 & & 1 & $(3.7)$ & & \\
\hline $\mathrm{Cw}^{\star} 16$ & 5 & $(9.8)$ & 2 & $(7.4)$ & & \\
\hline
\end{tabular}

Table 2 Frequencies of $H L A-D R B 1$ and $D Q$ alleles in patients with $S O$

\begin{tabular}{|c|c|c|c|c|c|c|}
\hline \multirow[b]{2}{*}{ Alleles } & \multicolumn{2}{|c|}{ Controls $(n=51)^{\star}$} & \multicolumn{2}{|c|}{ Patients $(n=27)$} & \multirow[b]{2}{*}{ Relative risk } & \multirow[b]{2}{*}{$p$ Value } \\
\hline & No & $(\%)$ & No & $(\%)$ & & \\
\hline $\mathrm{DRB} 1^{\star} 01$ & 12 & $(23.5)$ & 3 & $(11.1)$ & & \\
\hline DRB $1{ }^{\star} 03$ & 11 & $(21.6)$ & 8 & (29.6) & & \\
\hline $\mathrm{DRB} 11^{\star} 04$ & 13 & $(28.3)$ & 15 & $(55.5)$ & 3.7 & 0.017 \\
\hline $\mathrm{DRB} 1^{\star} 06$ & 1 & $(2.0)$ & 0 & & & \\
\hline $\mathrm{DRB} 1^{\star} 07$ & 16 & $(31.4)$ & 6 & $(22.2)$ & & \\
\hline DRB $1^{\star} 08$ & 2 & (3.9) & 1 & (3.7) & & \\
\hline DRB $1 \star 10$ & 1 & $(2.0)$ & 0 & & & \\
\hline DRB $1^{\star} 11$ & 7 & (13.7) & 1 & (3.7) & & \\
\hline $\mathrm{DRB} 1 \star 12$ & 1 & $(2.0)$ & 1 & (3.7) & & \\
\hline DRB $1 * 13$ & 8 & (15.7) & 5 & $(18.5)$ & & \\
\hline $\mathrm{DRB} 1^{\star} 15$ & 20 & $(39.2)$ & 6 & $(22.2))$ & & \\
\hline $\mathrm{DQA}^{\star}{ }^{\star} 01$ & 33 & $(67.3)$ & 13 & $(48.1))$ & & \\
\hline $\mathrm{DQA} 1{ }^{\star} 02$ & 17 & (34.7) & 6 & $(22.2)$ & & \\
\hline DQA $1{ }^{\star} 03$ & 12 & $(24.5)$ & 15 & $(55.5)$ & 3.9 & 0.014 \\
\hline $\mathrm{DQA1}{ }^{\star} 04$ & 2 & $(4.1)$ & 1 & $(3.7)$ & & \\
\hline $\mathrm{DQA} 1{ }^{\star} 05$ & 20 & $(40.8)$ & 11 & $(40.7)$ & & \\
\hline $\mathrm{DQB} 1{ }^{\star} 02$ & 23 & $(45.1)$ & 14 & (51.9) & & \\
\hline $\mathrm{DQB} 1{ }^{\star} 03$ & 27 & $(52.9)$ & 18 & $(66.7)$ & & \\
\hline $\mathrm{DQB} 1{ }^{\star} 04$ & 2 & $(3.9)$ & 1 & $(3.7)$ & & \\
\hline $\mathrm{DQB} 1{ }^{\star} 05$ & 16 & (31.4) & 4 & (14.8) & & \\
\hline $\mathrm{DQB1}{ }^{\star} 06$ & 23 & $(45.1)$ & 9 & (33.3) & & \\
\hline
\end{tabular}

$\star_{n}=49$ for DQA1 ${ }^{\star}$ alleles due to insufficient DNA.
Tables 1 and 2 respectively. For class I alleles, only $\mathrm{HLA}-\mathrm{Cw}^{\star} 03$ showed a significantly increased frequency $(R R=5.2, p=0.008)$ in $S O$ patients. For class II alleles, both HLA$\mathrm{DRB} 1{ }^{\star} 04(\mathrm{RR}=3.7, \mathrm{p}=0.017)$ and $\mathrm{DQA} 1^{\star} 03$ $(R R=3.9, p=0.014)$ were significantly increased in SO patients. No significant decrease in allele frequency was observed in SO patients compared with controls.

Higher resolution genotype frequencies of HLA-DRB1 and DQ alleles are shown in Table 3. Only DRB $1^{\star} 0404$ was significantly increased $(\mathrm{RR}=5.6, \mathrm{p}=0.045)$ in SO patients. When DQA $1{ }^{\star} 03$ positive patients had higher resolution typing, no significant increase in the frequency of any DQA $1^{\star} 03$ subtype was found.

When all significantly increased HLA allele frequencies were assessed for haplotype frequency, the haplotype frequency $\mathrm{Cw}^{\star} 03-$ $\mathrm{DRB} 1{ }^{\star} 04-\mathrm{DQA} 1{ }^{\star} 03$ was significantly increased $(R R=6.7, p=0.013)$ in $S O$ patients compared with controls (Table 4). A high relative risk for the associated haplotype $\mathrm{Cw}^{\star} 03$ $\mathrm{DQA} 1^{\star} 03 \quad(\mathrm{RR}=9.9, \quad \mathrm{p}=0.003)$ was also observed. For the DRB $1{ }^{\star} 04-\mathrm{DQA} 1{ }^{\star} 03$ haplotype, the relative risk was weaker $(R R=3.5$, $\mathrm{p}=0.024)$. However, at higher resolution of this haplotype, DRB $1^{\star} 0404-\mathrm{DQA} 1{ }^{\star} 0301$, the highest relative risk was found for any of the associated haplotypes $(R R=10.9, p=0.019)$. Although the DQA $1{ }^{\star} 0301$ frequency was not significantly increased alone, when in the significantly associated haplotype DRB1 ${ }^{\star} 0404-\mathrm{DQA} 1{ }^{\star} 0301$, all DQA ${ }^{\star} 0301$ positive patients possessed the $\mathrm{DQA}^{\star} 03011$ subtype. The haplotype frequency of $\mathrm{C} 3-\mathrm{DRB} 1{ }^{\star} 0404-\mathrm{DQA} 1{ }^{\star} 0301$ was not significantly increased in SO patients.

HLA HAPLOTYPE AND CLINICAL PHENOTYPE

To assess the influence of HLA gene variants/ haplotype on clinical phenotype and disease severity in SO, clinical features were assessed in SO patients with the significantly associated haplotype $\mathrm{DRB} 1^{\star} 04-\mathrm{DQA} 1{ }^{\star} 03$ (Table 5). Patients with SO and the DRB $1^{\star} 04-\mathrm{DQA} 1{ }^{\star} 03$ haplotype were significantly more likely to develop SO within 3 months of last ocular injury $(p=0.001)$, require less inciting events to develop SO ( $\mathrm{p}=0.038)$, or require more than $10 \mathrm{mg}$ oral prednisolone daily as maintenance therapy $(p=0.031)$ to control inflammatory activity. Although not reaching statistical significance, there was an increased frequency in SO patients with this haplotype of moderate to severe vitritis and recurrence of uveitis activity while on systemic therapy. In addition, there was an increased trend in patients without this haplotype to develop disease more than 1 year after last injury. As all $\mathrm{DRB}^{\star}{ }^{\star} 04$ positive patients also possessed the genotype DQA $1^{\star} 03$, it was not possible to determine whether the $\mathrm{DRB} 1{ }^{\star} 04$ or $\mathrm{DQA} 1{ }^{\star} 03$ genotype was associated with this clinical phenotype of increased disease severity. No significant difference was found in recognised clinical features of SO, such as Dalen-Fuchs nodules or choroidal neovascularisation, between patients with and without the DRB $1{ }^{\star} 04-\mathrm{DQA} 1^{\star} 03$ haplotype. In addition, there was no difference found in clinical phenotype or markers of 
Table 3 Frequencies of higher resolution subtypes of HLA-DRB1 and DQ alleles in patients with $S O$

\begin{tabular}{|c|c|c|c|c|c|c|}
\hline \multirow[b]{2}{*}{ Alleles } & \multicolumn{2}{|c|}{ Controls $(n=51)^{\star}$} & \multicolumn{2}{|c|}{ Patients $(n=27)$} & \multirow[b]{2}{*}{ Relative risk } & \multirow[b]{2}{*}{$p$ Value } \\
\hline & No & $(\%)$ & No & $(\%)$ & & \\
\hline $\mathrm{DRB} 1^{\star} 0103$ & 1 & $(2.0)$ & 3 & (11.1) & & \\
\hline $\mathrm{DRB} 1{ }^{\star} 0401$ & 8 & (15.7) & 9 & (33.3) & & \\
\hline $\mathrm{DRB} 1{ }^{\star} 0403$ & 1 & $(2.0)$ & 0 & & & \\
\hline DRB $1{ }^{\star} 0404$ & 2 & (3.9) & 5 & (18.5) & 5.6 & 0.045 \\
\hline DRB $1{ }^{\star} 0405$ & 0 & & 1 & $(3.7)$ & & \\
\hline $\mathrm{DRB} 1{ }^{\star} 0407$ & 0 & & 1 & (3.7) & & \\
\hline DRB1*0408 & 2 & $(3.9)$ & 1 & (3.7) & & \\
\hline $\mathrm{DRB} 1^{\star} 0413$ & 1 & $(2.0)$ & 0 & & & \\
\hline $\mathrm{DQA}^{\star}{ }^{\star} 0101$ & 12 & $(24.5)$ & 4 & $(14.8)$ & & \\
\hline DQA $1{ }^{\star} 0102$ & 8 & $(16.3)$ & 5 & (18.5) & & \\
\hline $\mathrm{DQA} 1{ }^{\star} 0201$ & 17 & $(34.7)$ & 6 & (11.8) & & \\
\hline DQA $1{ }^{\star} 0301$ & 7 & (14.3) & 8 & (15.7) & & \\
\hline DQA $1{ }^{\star} 0302$ & 0 & & 1 & $(3.7)$ & & \\
\hline DQA $1{ }^{\star} 0303$ & 6 & $(12.2)$ & 8 & $(29.6)$ & & \\
\hline DQA $1{ }^{\star} 0401$ & 2 & $(4.1)$ & 1 & $(3.7)$ & & \\
\hline DQA $1{ }^{\star} 0501$ & 20 & $(40.8)$ & 11 & $(40.7)$ & & \\
\hline $\mathrm{DQB} 1{ }^{\star} 0301$ & 16 & $(31.3)$ & 10 & $(37.0)$ & & \\
\hline DQB $1{ }^{\star} 0302 / 08$ & 8 & $(15.7)$ & 9 & (33.3) & & \\
\hline DQB1*0303 & 7 & (13.7) & 0 & & & \\
\hline
\end{tabular}

$\star_{\mathrm{n}}=49$ for DQA1 ${ }^{\star}$ alleles due to insufficient DNA.

Table 4 Frequencies of associated haplotypes in patients with SO

\begin{tabular}{|c|c|c|c|c|c|c|}
\hline \multirow[b]{2}{*}{ Alleles } & \multicolumn{2}{|c|}{ Controls $(n=51)^{\star}$} & \multicolumn{2}{|c|}{ Patients $(n=27)$} & \multirow{2}{*}{$\begin{array}{l}\text { Relative } \\
\text { risk }\end{array}$} & \multirow[b]{2}{*}{$p$ Value } \\
\hline & No & $(\%)$ & No & $(\%)$ & & \\
\hline $\mathrm{Cw}^{\star} 03-\mathrm{DRB} 1^{\star} 04-\mathrm{DQA} 1^{\star} 03$ & 3 & $(6.1)$ & 8 & $(29.6)$ & 6.7 & 0.013 \\
\hline $\mathrm{DRB} 1{ }^{\star} 04-\mathrm{DQA} 1{ }^{\star} 03$ & 13 & $(26.5)$ & 15 & $(55.5)$ & 3.5 & 0.024 \\
\hline $\mathrm{DRB} 1{ }^{\star} 0404-\mathrm{DQA} 1{ }^{\star} 0301$ & 1 & $(2.0)$ & 5 & $(18.5)$ & 10.9 & 0.019 \\
\hline $\mathrm{Cw} w^{\star} 03-\mathrm{DRB} 1^{\star} 04$ & 3 & $(5.9)$ & 8 & $(29.6)$ & 6.7 & 0.007 \\
\hline $\mathrm{Cw}^{\star} 03-\mathrm{DQA} 1{ }^{\star} 03$ & 2 & $(4.1)$ & 8 & $(29.6)$ & 9.9 & 0.003 \\
\hline
\end{tabular}

${ }^{\star} \mathrm{n}=49$ for DQA1 ${ }^{\star}$ alleles due to insufficient DNA.

Table 5 Influence of $H L A-D R B 1{ }^{\star} 04-D Q A 1^{\star} 03$ haplotype on clinical phenotype in patients with $S O$

\begin{tabular}{|c|c|c|c|}
\hline \multirow[b]{2}{*}{ Ocular signs* } & $\begin{array}{l}D R B 1^{*} 04-D Q A 1{ }^{*} 03 \\
\text { positive }(n=15) \dagger\end{array}$ & $\begin{array}{l}D R B 1^{*} 04-D Q A 1{ }^{*} 03 \\
\text { negative }(n=12) \neq\end{array}$ & \multirow[b]{2}{*}{$p$ Value } \\
\hline & No (\%) & No (\%) & \\
\hline $\mathrm{VA}<0.5 \$$ & $10(67)$ & $9(75)$ & \\
\hline Onset $<3$ months $\|$ & $13(87)$ & $3(25)$ & 0.001 \\
\hline Onset $>12$ months $\|$ & $2(13)$ & $5(42)$ & \\
\hline$>2$ inciting events\# & $4(27)$ & $8(67)$ & 0.038 \\
\hline Surgical cause of SO & $5(33)$ & $7(58)$ & \\
\hline Moderate/severe vitritis $\star \star$ & $11(73)$ & $5(42)$ & \\
\hline \multicolumn{4}{|l|}{ Persistent macular oedema $>3$} \\
\hline months & $7(47)$ & $5(42)$ & \\
\hline Disc oedema & $2(13)$ & $4(33)$ & \\
\hline Dalen-Fuchs nodules & $10(67)$ & $8(67)$ & \\
\hline Choroidal neovascularisation & $1(7)$ & $1(8)$ & \\
\hline Enucleation & $5(33)$ & $3(25)$ & \\
\hline Prednisolone $>10 \mathrm{mg} /$ day $\dagger+$ & $10(67)$ & $3(25)$ & 0.031 \\
\hline$>1$ immunosuppressive drug & $12(80)$ & $8(67)$ & \\
\hline Recurrence uveitis on therapy & $12(80)$ & $6(50)$ & \\
\hline
\end{tabular}

^Ocular signs during follow up in sympathising eyes only, where applicable.

†HLA-DRB $1{ }^{\star} 04-\mathrm{DQA} 1{ }^{\star} 03$ positive patients possessed both alleles.

$\ddagger$ HLA-DRB $1{ }^{\star} 04-\mathrm{DQA} 1{ }^{\star} 03$ negative patients did not possess either allele.

SWorst level of best corrected visual acuity.

$\|$ Onset of SO from last ocular injury.

\#Inciting event defined as penetrating eye trauma or surgery.

$\star \star$ Vitritis where vitreal haze/binocular indirect ophthalmoscopy score or cellular infiltrate was $2+$ or worse. †† Maintenance systemic prednisolone dose.

disease severity in SO patients with the $\mathrm{Cw}^{\star} 03-\mathrm{DRB} 1{ }^{\star} 04-\mathrm{DQA} 1{ }^{\star} 03$ haplotype, or with the individual genotypes $\mathrm{Cw}^{\star} 03$, DRB $1{ }^{\star} 0404$ or DQA $1{ }^{\star} 0301$ (data not shown) compared with SO patients without these HLA gene variants.

\section{Discussion}

The most important finding of this DNA typing study of sympathetic ophthalmia is that there is a similar association with HLA$\mathrm{DRB} 1{ }^{\star} 04$ and $\mathrm{DQA} 1{ }^{\star} 03$ genotypes in white patients and Japanese patients with SO. Of equal importance is the finding that the DRB $1{ }^{\star} 04-\mathrm{DQA} 1{ }^{\star} 03$ haplotype is a marker of more severe clinical phenotype in SO, with increased disease susceptibility and severity, similar to $\mathrm{VKH}$, which has identical HLA associations and increased disease severity associated with $\mathrm{DRB} 1{ }^{\star} 04$ gene variants. ${ }^{1{ }^{12}}$

Previous serological HLA studies of SO have reported an increase in both HLA-DR4 and DQ3 in non-Japanese and Japanese patients. ${ }^{1619}{ }^{20}$ Previous studies outside of Japan have been small and control groups were inappropriate as they were too large, falsely increasing the power of statistical analysis, ${ }^{8} 20$ did not have racial matching, or were not typed in the same laboratory at the same time as the patients. $^{2026}$ Our SO patient $(\mathrm{n}=27)$ and control $(n=51)$ groups are relatively small in statistical terms, and interpretation of the data must be more cautious with the smaller SO patient subgroups in phenotypic analysis. However, this is the largest population based (UK and Ireland) cohort of SO patients yet described, with rigorous matching of controls to each patient, and all DNA based typing was performed in the same laboratory at the same time. With the greater accuracy and resolution of DNA based typing compared to serology, greatly reducing the chance of a type 1 error, we have not performed Bonferroni's correction for multiple comparison procedures, similar to other recent DNA based HLA studies. ${ }^{7216}$ There has been only one previous DNA based HLA study of SO, on 16 Japanese patients, which found significant associations with HLA-DRB $1^{\star} 0405$, DQA $1{ }^{\star} 03$, and DQB $1{ }^{\star} 0401 .{ }^{16}$

HLA disease associations are dependent on the prevalence of a specific HLA allele in the population and the evolution of particular linkage disequilibria-for example, between HLA-DR and HLA-DQ, is also dependent on ethnic background. Japan has a relatively homogeneous ethnic genetic island population and HLA disease associations with particular genotypes may not be as relevant outside of Japan. Owing to strong linkage disequilibrium between $\mathrm{DRB} 1{ }^{\star} 0405$ and $\mathrm{DQB} 1{ }^{\star} 0401$ in Japan only, ${ }^{17} 18$ and lack of serological SO association with DQ4 in North American patients, ${ }^{20}$ the authors of the Japanese study suggested that $\mathrm{DQB} 1^{\star} 0401$ was unlikely to control the development of SO but were unable make a definite conclusion. Our study supports this finding as $\mathrm{DQB} 1^{\star} 0401$ was not associated with SO, nor was $\mathrm{DRB} 1^{\star} 0405$, probably because the prevalence of DRB $1^{\star} 0405$ is low outside the Far East. ${ }^{17}{ }^{18}$ The subtypes of $\mathrm{DRB} 1^{\star} 04$ are invariably linked with DQA $1{ }^{\star} 03$ across all races. ${ }^{18}$ However, DQA ${ }^{\star} 03$ is linked with other types, such as subtypes of $\mathrm{DRB} 1^{\star} 08, \mathrm{DRB} 1^{\star} 09$, and $\mathrm{DRB} 1{ }^{\star} 12$, and these other types were not increased in the patients with SO in our study where only DRB1*04 (0404) was significantly increased. Our data support the finding that 
HLA-DRB $1^{\star} 04$, and not its subtypes, controls SO susceptibility in different ethnic groups.

Although SO and $\mathrm{VKH}$ in Japan are reported to have identical HLA associations with $\mathrm{DRB} 1^{\star} 0405$ and $\mathrm{DQB} 1^{\star} 0401,{ }^{15}{ }^{16}$ another Japanese VKH study has discounted the importance of the $\mathrm{DRB} 1^{\star} 0405$ or DQB $1{ }^{\star} 0401$ genotype, due to strong Japanese linkage disequilibrium for this haplotype, and suggested that $\mathrm{DQA}^{\star}{ }^{\star} 0301$ is the primary genotype for $\mathrm{VKH}$ susceptibility with assistance by the $\mathrm{DRB} 1^{\star} 04$ gene variant. ${ }^{12}$ A more recent Japanese $S O$ study also found an association with $\mathrm{DQA} 1{ }^{\star} 03$ but no $\mathrm{DQA1}{ }^{\star} 03$ subtyping was performed. ${ }^{16}$ Our study in patients with SO did not find an association with the HLA-DQA $1{ }^{\star} 0301$ genotype, which occurred only when in the haplotype DRB $1{ }^{\star} 0404-\mathrm{DQA} 1{ }^{\star} 0301$, whereas the DRB $1{ }^{\star} 0404$ genotype alone was associated, which suggests that a DRB $1^{\star} 04$ gene variant, rather than DQA $1^{\star} 0301$, controls SO susceptibility. However, the theory of combined allelic predisposition is supported by the finding that the HLA DRB $1^{\star} 04-\mathrm{DQA} 1{ }^{\star} 03$ haplotype confers increased SO disease susceptibility, through earlier disease onset and the need for fewer inciting events to initiate disease, and increased disease severity but the DQA ${ }^{\star} 03$ genotype may be of secondary importance. The possession of $\mathrm{DRB} 1^{\star} 04$ gene variants has also been found to increase disease severity in rheumatoid arthritis, another autoimmune disease. ${ }^{27}$ The higher resolution DRB1*0404-DQA1*0301 haplotype, although significantly associated, was present in only five patients which did not allow meaningful comparison of clinical phenotype in patients with and without this haplotype.

Our study differs from previous Japanese data in that $\mathrm{DRB} 1{ }^{\star} 0404$, and not $\mathrm{DRB} 1^{\star} 0405$, which differ by two amino acids (AA) in sequence, was associated with SO. This association was also weaker as the relative risk for DRB $1{ }^{\star} 0404$ was 5.6 in our study compared with 13.7 for $\mathrm{DRB} 1{ }^{\star} 0405$ in Japan. ${ }^{16}$ The two AA difference comparing DRB $1^{\star} 0404$ and $\mathrm{DRB} 1{ }^{\star} 0405$, where asparagine is replaced by serine at position 57 and valine is replaced by glycine at position 86 , occurs in the hypervariable extracellular domains of these class II molecules where the peptide binding groove is formed. This can significantly alter the chemicospatial relations that determine peptide binding affinity. Altered peptide binding affinity, in turn, influences peptide presentation to CD4+ $\mathrm{T}$ cells, central to disease initiation in EPU. Defining a particular HLA class II association, such as $\mathrm{DRB} 1{ }^{\star} 0404$ or $\mathrm{DRB} 1^{\star} 0405$, and knowing its AA sequence and three dimensional structure, could allow identification of certain disease inducing peptides through peptide binding affinity. It has been observed that HLA alleles associated with autoimmunity are usually poor peptide binders ${ }^{28}$ and this approach could be used in SO to identify candidate autoantigens through predicted or tested peptide binding affinity. Certain peptides contain anchor residues that define allele specific motifs common to all peptides capable of binding to a specific HLA molecule. Tolerogenic peptides could be identified through allele specific motifs allowing high affinity competitive binding of either inert peptides, stabilising the HLA complex and preventing access to the peptide binding groove, or immunomodulatory peptides with anti-inflammatory or regulatory cytokine responses. ${ }^{29}$

The association with HLA-Cw ${ }^{\star} 03$ in patients with SO has not been reported previously, nor has this allele been previously found to be associated with other categories of uveitis or autoimmune disease. However, increased cytotoxic $\mathrm{T}$ cell lytic activity has been observed in $\mathrm{HLA}-\mathrm{Cw}^{\star} 03$ positive patients against melanoma cell lines ${ }^{30}$ and this may support a role for melanin associated antigens in the pathogenesis of $\mathrm{Cw}^{\star} 03$ restricted $\mathrm{SO}$.

Genetic susceptibility to $\mathrm{SO}$ may not reside with $\mathrm{DRB} 1{ }^{\star} 0404$ or $\mathrm{DRB} 1{ }^{\star} 0405$, or other $\mathrm{DRB} 1{ }^{\star} 04$ variants, with varying heuristic effects on HLA class II peptide binding affinity and $T$ cell activation or selection. The DRB1*0404-DQA1*0301 haplotype association, and weaker association with DRB $1{ }^{\star} 0404$ compared to $\mathrm{DRB} 1{ }^{\star} 0405$ in Japan, may point to primary susceptibility with a gene involved in the immune response in the HLA class II region tightly linked to HLA-DR and HLA-DQ genes, such as HLA-DM, HLADO, TAP, LMP, and tapasin. ${ }^{78}$ HLA-DM genes are closely involved in peptide editing, regulate peptide binding to HLA class II molecules by facilitating low affinity peptide exchange, and may allow selection of immunodominant epitopes. ${ }^{31}{ }^{32}$ Recent work has found that HLA-DM gene variants are associated with rheumatoid arthritis ${ }^{33}$ and type 1 diabetes mellitus, ${ }^{34}$ where class II antigen processing is important. MHC restriction and both genetic susceptibility and disease severity association have been demonstrated in very well defined animal models of uveitis, ${ }^{13}$ but it has been much more difficult to show this in the genetically diverse human clinical situation. Further gene mapping and analysis of genetic polymorphisms in patients with SO may determine the precise genes responsible for susceptibility and disease severity in SO.

Presented in part at the Annual Meeting for Research and Vision in Ophthalmology, Florida, May 2000.

This study was funded by the Wellcome Trust which supported DJK with a Vision Research training fellowship. The authors also wish to gratefully acknowledge the data contribution of 20 ophthalmologists throughout the United Kingdom and Republic of Ireland, the technical assistance of Joanne Harris, Tissue Typing Laboratory, and the statistical advice of Dr Gordon Prescott, Department of Public Health Medicine, University of Aberdeen.

1 Kilmartin DJ, Dick AD, Forrester JV. Prospective su lance of sympathetic ophthalmia in the United Kingdom and Republic of Ireland. Br f Ophthalmol 2000;84:259-63.

2 Chan CC, Roberge FG, Whitcup SM, et al. Thirty-two cases of sympathetic ophthalmia: a retrospective study at the National Eye Institute, USA from 1982-1992. Arch Ophthalmol 1995;113:597-600.

3 Forrester JV. New concepts on the role of autoimmunity in the pathogenesis of uveitis. Eye 1992;6:433-46.

4 Chan CC, Roberge FG. Sympathetic ophthalmia. In: Pepose JS, Holland GN, Wilhelmus FR, eds. Ocular infection and immunity. St Louis: Mosby; 1996:724.

5 Liversidge J, Dick A, Cheng Y-F, et al. Retinal antigen specific lymphocytes, TCR-gamma delta $\mathrm{T}$ cells and CD5+ B cells cultured from the vitreous in acute sympathetic ophthalmitis. Autoimmunity 1993;15:257-66. 
6 Chan CC, BenEzra D, Rodrigues MM, et al. Immunohistochemistry and electron microscopy of choroidal infiltrates
and Dalen-Fuchs nodules in sympathetic ophthalmia. and Dalen-Fuchs nodules in
Ophthalmology 1985;92:580-90.

7 Davey MP, Rosenbaum JT. The human leukocyte antigen complex and chronic ocular inflammatory disorders. Am $\mathcal{F}$ Ophthalmol 2000;129:235-43.

8 Mizuki N, Inoko H, Ohno S. Role of HLA and T lymphocytes in the immune response. Ocul Immunol Inflamm 1994;2:57-91.

9 Bloch-Michel E, Frau E. Birdshot chorioretinopathy and HLA-A29+ and HLA-A29- idiopathic reinal vasculitis:
comparative study of 56 cases. Can $\mathcal{F}$ Ophthalmol 1991;26: 361-6.

10 Verity DH, Wallace GR, Vaughan RW, et al. HLA and tumour necrosis factor (TNF) polymorphisms in ocular Behçet's disease. Tissue Antigens 1999;54:264-72.

11 Islam SMM, Numaga J, Matsuki K, et al. Influence of HLADRB1 gene variation on the clinical course of Vogt35:752-6.

12 Islam SMM, Numaga J, Fujino Y, et al. HLA class II genes in Vogt-Koyanagi-Harada disease. Invest Ophthalmol Vis Sci 1994;35

13 Caspi RR. Immunogenetic aspects of clinical and experimental uveitis. Reg Immunol 1992;4:321-30.

14 Rao NA, Marak GE. Sympathetic ophthalmia simulating Vogt-Koyanagi-Harada's disease: a clinico-pathologic study of four cases. Fpn F Ophthalmol 1983;27:506-11.

15 Shindo Y, Inoko H, Yamamoto T, et al. HLA-DRB1 typing of Vogt-Koyanagi-Harada's disease by PCR-RFLP and the strong association with DR Ophthalmol 1994;78:223-6.

16 Shindo Y, Ohno S, Usui M, et al. Immunogenetic study of sympathetic ophthalmia. Tissue Antigens 1997;49:111-15.

17 Geer L, Terasaki PI, Gjertson DW. Gene frequencies and world maps of their distributions. In: Gjertson DW, Terasaki PI, eds. HLA 1998. Kansas: American Society for Histocompatibility and Immunogenetics;1998:327-65.

18 Imanishi T, Akaza T, Kimura A, et al. Allele and haplotype frequencies for HLA and complement loci in various ethnic frequencies for HLA and complement loci in various ethnic groups. In: Tsuji K, Aizawa M, Sasazuki T, eds. HLA 1992. Proceedings of the Eleventh International Histocompatibility Workshop and Confe

19 Ohno S, Ichibayashi Y, Ichiishi A, et al. Sympathetic ophthalmia and HLA. In: Aizawa M, ed. HLA in Asia-Oceania. Sapporo: Hokkaido University Press, 1996:740-2.
20 Davis JL, Mittal KK, Freidklin V, et al. HLA associations and ancestry in Vogt-Koyanagi-Harada disease and sympathetic ophthalmia. Ophthalmology 1990;97:1137-42.

21 Nussenblatt RB, Palestine AG, Chan CC, et al. Standardization of vitreal inflammatory activity in intermediate and posterior uveitis. Am f Ophthalmol 1985;92: 467-71.

22 Miller SA, Dykes DD, Polesky HF. A simple salting out procedure for extracting DNA from human nucleated cells. Nucleic Acids Res 1988;16:1215.

23 Olerup O, Zetterquest H. HLA-DRB ${ }^{\star} 01$ subtyping by allele-specific PCR amplification: a sensitive, specific and rapid technique. Tissue Antigens 1991;37:197-204.

24 Robinson J, Malik A, Parham P, et al. IMGT/HLA database-a sequence database for the human major histocompatibility complex. Tissue Antigens 2000;55:280-7.

25 Woolf $\mathrm{B}$. On estimating the relation between blood group and disease. Ann Hum Genet 1955;19:251-3.

26 Reynard M, Shulman IA, Azen SP, et al. Histocompatibility antigens in sympathetic ophthalmia. Am $\mathcal{f}$ Ophthalmol 1983;95:217-21.

27 Weyand CM, Hicok KC, Conn DL, et al. The influence of HLA-DRB1 genes on disease severity in rheumatoid arthritis. Ann Intern Med 1992;117:801-6.

28 Carrasco-Marin E, Shimizu J, Kanagawa O, et al. The class II MHC I-Ag7 molecules from non-obese diabetic mice are poor peptide binders. F Immunol 1996;156:450-8.

29 Mason D, Powrie F. Control of immune pathology by regulatory T cells. Curr Opin Immunol 1998;10:649-55.

30 LeMay LG, Kan-Mitchell J, Goedegebuure P, et al. Detection of melanoma-reactive CD4+ HLA-clas I-restricted cytotoxic $\mathrm{T}$ cell clones with long-term assay and pretreatment of targets with interferon-gamma. Cancer Immunol Imunother 1993;37:187-94.

31 Van Ham SM, Gruneberg U, Malcherek G, et al. Human histocompatibility leukocyte antigen (HLA)-DM edits peptides presented by HLA-DR according to their ligand binding motifs. F Exp Med 1996;184:2019-24.

$32 \mathrm{Ma}$ C, Whiteley PE, Cameron PM, et al. Role of APC in the selection of immunodominant $\mathrm{T}$ cell epitopes. $\mathcal{F}$ Immunol 1999;163:6413-23.

33 Perdriger A, Guggenbuhl P, Chales G, et al. Positive association of the HLA-DMB $1{ }^{\star} 0101-0101$ genotype with rheumatoid arthritis. Rheumatology 1999;38:448-52.

34 Siegemund T, Donner H, Braun J, et al. HLA-DMA and HLA-DMB alleles in German patients with type 1 diabetes mellitus. Tissue Antigens 1999;54:291-4. 